\title{
Wall-to-Suspension Heat Transfer in a CFB Downcomer
}

\author{
Huili Zhang, ${ }^{1}$ Jan Degrève, ${ }^{1}$ Raf Dewil, ${ }^{2}$ and Jan Baeyens ${ }^{3}$ \\ ${ }^{1}$ Department of Chemical Engineering, Bio- \& Chemical Systems Technology, Reactor Engineering and Safety Section, \\ KU Leuven, Celestijnenlaan 200F, 3001 Heverlee, Belgium \\ ${ }^{2}$ Department of Chemical Engineering, Process and Environmental Technology Lab, KU Leuven, Jan De Nayerlaan 5, \\ 2860 Sint-Katelijne-Waver, Belgium \\ ${ }^{3}$ School of Engineering, University of Warwick, Coventry CV4 7AL, UK \\ Correspondence should be addressed to Huili Zhang; huili.zhang@cit.kuleuven.be
}

Received 21 June 2015; Revised 11 August 2015; Accepted 18 August 2015

Academic Editor: Franco Berruti

Copyright (c) 2015 Huili Zhang et al. This is an open access article distributed under the Creative Commons Attribution License, which permits unrestricted use, distribution, and reproduction in any medium, provided the original work is properly cited.

\begin{abstract}
With the development of circulating fluidized beds (CFB) and dense upflow bubbling fluidized beds (UBFB) as chemical reactors, or in the capture and storage of solar or waste heat, the associated downcomer has been proposed as an additional heat transfer system. Whereas fundamental and applied research towards hydrodynamics has been carried out, few results have been reported on heat transfer in downcomers, even though it is an important element in their design and application. The wall-to-suspension heat transfer coefficient (HTC) was measured in the downcomer. The HTC increases linearly with the solids flux, till values of about $150 \mathrm{~kg} / \mathrm{m}^{2} \mathrm{~s}$. The increasing HTC with increasing solid circulation rate is reflected through a faster surface renewal by the downflow of the particle-gas suspension at the wall. The model predictions and experimental data are in very fair agreement, and the model expression can predict the influence of the dominant parameters of heat transfer geometry, solids circulation flow, and particle characteristics.
\end{abstract}

\section{Introduction}

The Downcomer within Gas/Solid Systems. Circulating fluidized bed (CFB) and bubbling fluidized bed (BFB) technologies have been widely accepted, especially for various gas-solid reactions [1-4]. CFB and dense upflow bubbling fluidized beds (UBFB) are presented as potential technologies for solar heat capture $[5,6]$. The CFB and UBFB have been studied in detail, especially towards the wall-to-bed heat transfer and for the proper hydrodynamic design of the systems. Previous research results, mostly for CFB, and comprehensive reviews on this subject [7-11] have been recently confirmed and complemented by the present coauthors [1215]. Specific heat transfer applications of UBFB to solar energy capture have been discussed by, for example, Flamant et al. [5]. With the development of the CFB and UBFB, the associated recycling downcomer has been proposed as an alternative or/and additional heat transfer system. While fundamental and applied research has been carried out $[16,17]$, few results have been reported on heat transfer in downcomers, even though it is an important element in their design and application.

Compared to the moving bed and downcomer concepts, introducing relative particle movement, such as in BFB, $\mathrm{UBFB}$, or CFB, improves the heat transfer and gas/solid mixing, but abrasion, erosion, and particle elutriation increase with increased gas velocity. BFB and UBFB, operating with A-type powders at low velocity, provide an excellent balance between high heat transfer rates and particle stability. CFB systems offer the advantage of operating at high solid circulation fluxes ( $\gg 500 \mathrm{~kg} / \mathrm{m}^{2} \mathrm{~s}$ ) thus being capable of conveying a significant amount of sensible heat, however at a somewhat lower heat transfer coefficient than in BFB and UBFB, and at a higher risk of abrasion and attrition. The application of a higher $U$ will however necessitate appropriate dedusting equipment and heat recovery on the exhaust gas to limit heat losses. The BFB, CFB, and moving bed concepts can however be applied in the thermal block of a solar energy plant. The hot storage in a powder circulation loop will generally be 


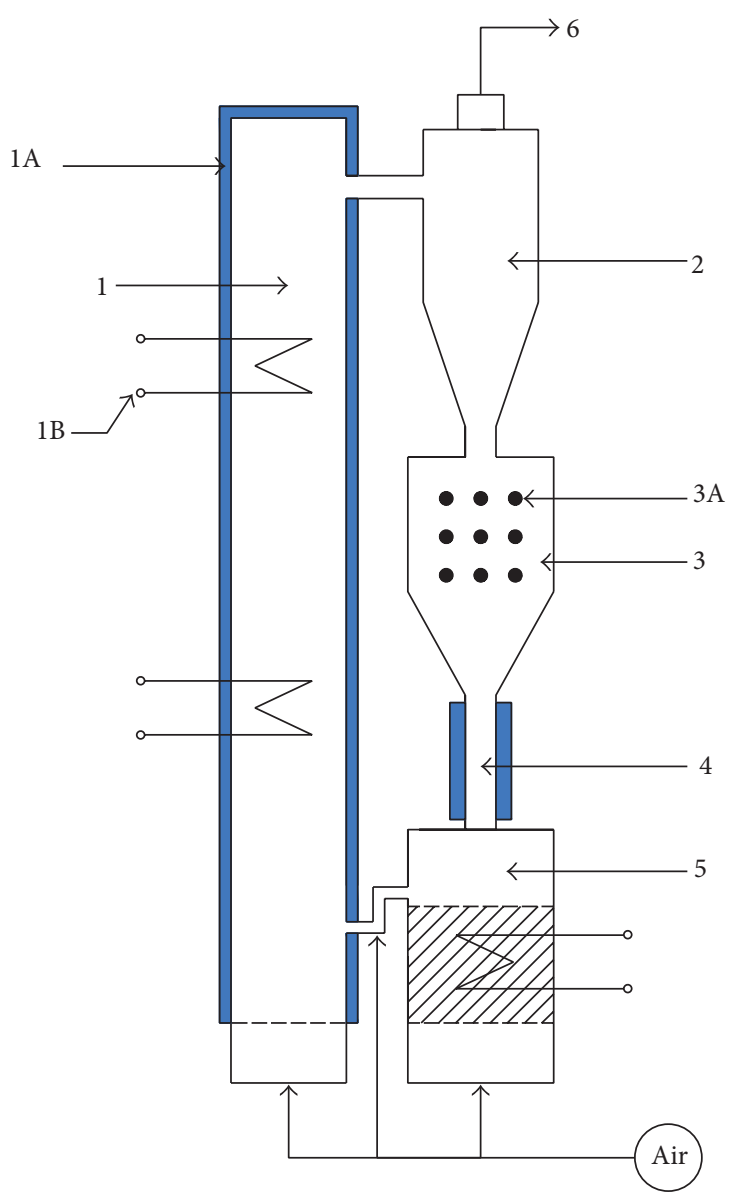

FIGURE 1: Layout for various applications. (1) Riser with wall-mounted heat exchanger (1A) and/or in-bed heat exchanger (1B, less common); (2) cyclone; (3) storage hopper, possibly with in-bed encapsulated PCM (3A); (4) downcomer, with wall-mounted heat recovery; (5) secondary fluidized bed, with embedded heat exchanger; (6) exhaust to further heat recovery and dedusting; (A) application for gas-solid reaction, for example, combustion (1A, 4, and 5), (B) application for solar energy capture and storage and steam generation (1 (without 1A), 3/3A, 4, and $5)$, and application for gas-catalytic reaction with in-bed heat transfer $(1 \mathrm{~B}, 4)$.

of the moving bed type $[18,19]$. The downcomer section can be used for partial heat recovery. The excellent heat transfer characteristics of powder beds moreover facilitate the integration of encapsulated phase change materials (E-PCM), as temporary heat storage medium $[13,20]$.

In solar energy applications, the loop is generally composed of a CFB or UBFB heat receiver, a hot storage silo fed from the discharge of the receiver, a downcomer with wallmounted heat exchanger, and finally feeding a fluid bed heat exchanger (FBHE), where the particles transmit their energy to submerged tubes inside whom a working fluid (e.g., steam) is generated and further expanded in a turbine: the FBHE is a common device in the electrical power industry (mostly implemented for coal and biomass combustion in fluidized beds). A tentative layout is given in Figure 1 for different applications to reaction engineering or solar energy capture, storage, and reuse.

An additional use of the downcomer for heat transfer is illustrated by Van de Velden et al. [21, 22] and Brems et al. [23] for the pyrolysis of biomass and solid plastic waste, respectively: the inert gas carrier (sand) is preheated to the temperature required to pyrolysis and for feed stock preheating.

The Operation of the Downcomer. In the downcomer, both entrained gas and solids mostly flow in the same direction as gravity. If the solids downward flux is limited, upward flow of the gas has been reported and is also demonstrated in Figure 2, where $V_{g}$ is upwards till $G$ exceeds $\sim 130 \mathrm{~kg} / \mathrm{m}^{2}$ s. Compared to the riser, radial distributions of solids concentration and particle velocity are much more uniform, resulting in a more uniform gas-solids flow structure [16, $17,24]$. The heat transfer behaviour in the downcomer is therefore expected to be different from that in the riser, although some of the influencing factors may be the same in both the downcomer and the riser.

In the downcomer, there are two hydrodynamic flow sections along the axial direction: the acceleration section below the feeding point of the downcomer and the constant velocity section, as illustrated by Zhu et al. [16]: in the acceleration zone, solids are accelerated by both the gas flow and the gravity until the solids velocity is equal to the gas 


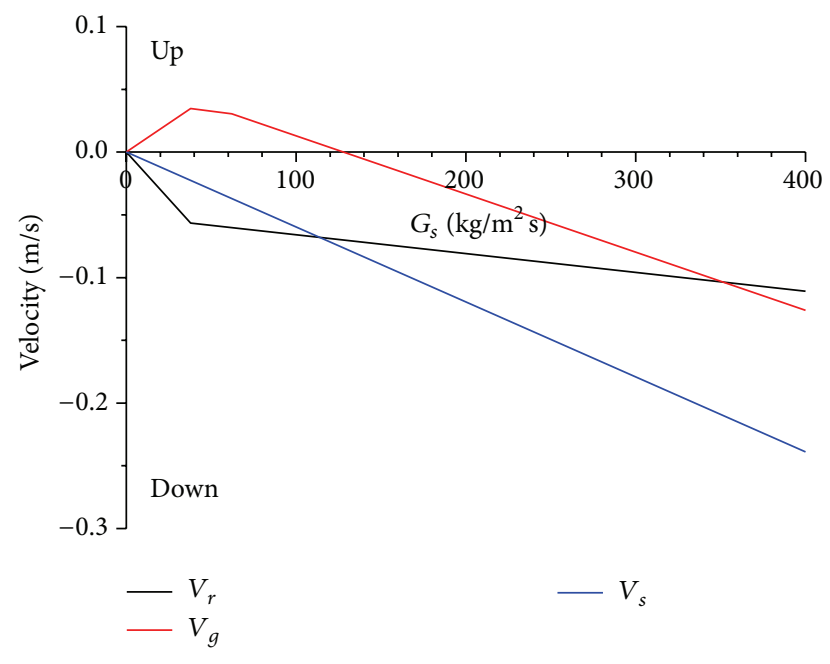

FIgURE 2: Velocity profiles in the downcomer, for downwards flow $V_{r}=V_{s}-\left(-V_{g}\right)$.

velocity. The pressure drop is negative in this section. Particles are further accelerated by gravity but resisted by the gas flow. Particle velocity then overtakes the gas velocity and increases further until the gas drag force (in the upward direction) counterbalances the gravitational force. In this section, the pressure drop is positive and gradually increases. When the gravitational force is in balance with the drag, both particle and gas velocities remain constant. The pressure drop also becomes constant. This section is the constant velocity section.

The axial solids holdup and heat transfer variations also follow the two-section pattern. The average suspension density decreases along the bed depth and so does the heat transfer coefficient: both profiles of heat transfer and solids holdup decrease sharply in the first acceleration section, and then the trend becomes smooth further down the bed. In the constant velocity section, the heat transfer coefficient and solids holdup become almost constant.

The existence of both zones is illustrated when calculating the air velocity in the downcomer. The Ergun equation [25], modified as below, enables us to calculate the velocity of the air in the downcomer:

$$
\begin{aligned}
\frac{\Delta P_{\mathrm{DC}}}{L_{\mathrm{DC}}}= & 150\left(\frac{1-\varepsilon_{\mathrm{mf}}}{\varepsilon_{\mathrm{mf}}}\right)^{2} \frac{\mu_{g} V_{r}}{d_{\mathrm{sv}}^{2}} \\
& +1.75\left(\frac{1-\varepsilon_{\mathrm{mf}}}{\varepsilon_{\mathrm{mf}}}\right) \frac{\rho_{g} V_{r}^{2}}{d_{\mathrm{sv}}},
\end{aligned}
$$

where

$$
\begin{aligned}
V_{s} & =\frac{G_{\mathrm{DC}}}{\rho_{B}}, \\
V_{g} & =\frac{U}{\varepsilon_{\mathrm{mf}}}, \\
V_{r} & =V_{s}-V_{g} .
\end{aligned}
$$

If, for a given $\Delta P_{\mathrm{DC}}, V_{g}$ is negative, upflow of gas through the downcomer occurs. A typical calculated profile is given in Figure 2.

Relevant literature findings concerning the hydrodynamics and heat transfer in downcomers are summarized in Table 1. Within the cited literature both embedded and wallmounted heat transfers have been investigated.

Objectives of the Research. In the present study, experimental data of heat transfer for sand and limestone particles is obtained from a cocurrent downflow bed. Since results on the HTC from the riser wall to the upward flowing suspension in the same rig were previously published $[13,15]$, the study only assesses the heat transfer from the wall of the downcomer to the downflowing suspension for 4 B-type powders of equal density. The HTC will be measured in the region of constant downward flux, that is, between 1.2 and $1.4 \mathrm{~m}$ below the downcomer feeding point. Analysis of the HTC will demonstrate a significant effect of the solids circulation rate and a less pronounced effect of the particle size. Finally, a surface renewal model will be used to predict the HTC, whilst predictions and experimental data will be compared.

\section{Experimental Setup and Procedure: Wall-to-Bed Heat Transfer}

The riser and downcomer are depicted in Figure 3. The riser consists of $50 \mathrm{~mm}$ ID pipe approximately $2.5 \mathrm{~m}$ high. Solids circulation was achieved via $100 \mathrm{~mm}$ ID downcomer and $50 \mathrm{~mm}$ ID $L$-valve. Air is supplied to the riser through a distributor plate and leaves the system through a cyclone after the riser's exit. Pressure taps are located along the height of the riser and downcomer and connected to a data acquisition system. Flow rates and pressure drops were monitored. A concentric wall cooler of $10 \mathrm{~cm}$ length was installed in the riser at $1.2 \mathrm{~m}$ above the reentry point of the $L$-valve, hence within the fully developed riser flow made. The downcomer was heated through a $0.2 \mathrm{~m}$ long concentric exchange surface, $1.2 \mathrm{~m}$ below its feeding point from the cyclone, hence in the contact solid velocity section. Heat supply was by hot water or thermal fluid (Santotherm 350). The wall surface temperature was measured using a resistance thermocouple welded onto the wall. Additional Thermocoax thermocouples $(0.1 \mathrm{~mm}$ OD) were installed at various locations in the riser and downcomer, as well as in the feeding and overflow lines of the fluid, as indicated in Figure 3. The heat input was set at such a value that the bed temperature ranged from 30 to $40^{\circ} \mathrm{C}$, for wall temperature in excess of $80^{\circ} \mathrm{C}$. Pressure probes were located at different heights in the rig, as illustrated in Figure 3.

The experiments consisted of starting the gas flow to the riser, followed by the flow of the fluidizing gas to the solids $L$-valve feeder. The flow rates of gas and solids were then set to the desired values, the heat input into the system was fixed, and the system was allowed to stabilize over a period of about 30 minutes, during which flow rate, temperatures, and pressures were monitored and recorded. 
TABLE 1: Literature review of downcomer operation and heat transfer.

\begin{tabular}{|c|c|}
\hline Van de Velden et al., 2008 and 2010 [21, 22] & $\begin{array}{l}\text { The downcomer of a CFB is used to supply the endothermic heat of pyrolysis of biomass } \\
\left(450-550^{\circ} \mathrm{C}\right) \text {, through wall-to-sand preheating }\end{array}$ \\
\hline Brems et al., 2013 [14] & $\begin{array}{l}\text { The downcomer of a CFB pyrolysis reaction of solid (wall-to-bed) plastic waste can be used } \\
\text { to supply the endothermic heat of pyrolysis by heating the sand carrier to appropriate } \\
\text { temperatures }\end{array}$ \\
\hline Baumann et al., 2012 and 2014 [26, 27] & $\begin{array}{l}\text { The effect of powder properties on their use as heat transfer media in a moving bed heat } \\
\text { exchanger (with embedded tubes) was investigated in view of concentrated solar power } \\
\text { applications }\end{array}$ \\
\hline Baird et al., 2008 [28] & $\begin{array}{l}\text { Empirical and model fittings of experimental data from the wall to a moving bed of nickel } \\
\text { pellets were investigated }\end{array}$ \\
\hline Zhang et al., 1999 [29] & $\begin{array}{l}\text { Characterization of local and overall gas-solid flow structure by measuring the distribution } \\
\text { of local solids holdups and pressure gradients along the downcomer }\end{array}$ \\
\hline Zhang and Zhu, 2000 [30] & Local solids fluxes were also calculated from the local particle velocities and solids holdups \\
\hline Ball and Zhu, 2001 [31] & $\begin{array}{l}\text { The effect of gas velocity, solids circulation rate, and axial and radial positions on the local } \\
\text { solids flux in a gas-solids downcomer of a fluidized bed }\end{array}$ \\
\hline Chen and Li, 2004 [32] & $\begin{array}{l}\text { Probability density distribution was studied through low and high density downcomer } \\
\text { operations and confirmed that solids flux is affecting the solids holdup }\end{array}$ \\
\hline Lehner and Wirth, 1999 [33] & $\begin{array}{l}\text { Experimental investigations concerning the local and cross-sectional solids distribution } \\
\text { were conducted under different operating conditions and with different solids }\end{array}$ \\
\hline Kim et al., 2001 [34] & $\begin{array}{l}\text { The effects of operative conditions of subbituminous coal gasification in a downcomer } \\
\text { reactor were experimentally determined }\end{array}$ \\
\hline Ma and Zhu, 1999 [35] & $\begin{array}{l}\text { Local heat transfer was investigated in a gas-solid concurrent downflow downcomer of a } \\
\text { fluidized bed with FCC particles. HTC is closely related to the hydrodynamics, with bed } \\
\text { suspension density being the most influential factor }\end{array}$ \\
\hline Tamarin and Gorbachev, 1968 [36] & $\begin{array}{l}\text { Heat transfer coefficient between a bed of moving slag particles and a vertical surface was } \\
\text { experimentally determined in several gas atmospheres }\end{array}$ \\
\hline Kim et al., 1999 [37] & $\begin{array}{l}\text { Bed-to-wall heat transfer coefficient was determined in a downcomer reactor and results } \\
\text { showed suspension density, gas convection, and particle size as influential factors. A model } \\
\text { was proposed to predict the bed-to-wall HTC }\end{array}$ \\
\hline Lehner and Wirth, 1999 [38] & $\begin{array}{l}\text { The effect on the local and overall solids circulation in a downcomer was studied for various } \\
\text { gas/solids distributors }\end{array}$ \\
\hline Obuskovic, 1988 [39] & $\begin{array}{l}\text { HTC was measured for a single vertical tube immersed in a moving packed bed of glass } \\
\text { beads, sand, or copper in air at atmospheric pressure in order to obtain a general predictive } \\
\text { equation }\end{array}$ \\
\hline Peters and Dziugys, 2012 [40] & $\begin{array}{l}\text { Heat transfer prediction in a fixed and moving packed bed by extended discrete element } \\
\text { method }\end{array}$ \\
\hline Basu et al., 2013 [41] & $\begin{array}{l}\text { Investigation of heat transfer to cross and vertical tubes in a standpipe of a circulating } \\
\text { fluidized bed boiler. A model provides a fair agreement with experimental results }\end{array}$ \\
\hline Niegsch et al., 1994 [42] & $\begin{array}{l}\text { The heat transfer of a steam heated tube bundle in a moving bed was investigated. Detailed } \\
\text { heat transfer phenomena were described and a modelling approach was proposed }\end{array}$ \\
\hline Meier et al., 2009 [43] & $\begin{array}{l}\text { An alternative solution to heat and mass transfer problems was presented, by casting the } \\
\text { system of equations into a matrix of the Sturm-Liouville type }\end{array}$ \\
\hline
\end{tabular}

The axial pressure profile was recorded during each experiment in order to make sure that the suspension entering the heated section was in fully developed flow conditions, hence with a constant $\Delta P$ throughout the experimental measurement.

From the known exposed surface area, $A_{\mathrm{ex}}$, and measured temperature difference, $\Delta T$, the heat transfer coefficient was calculated for the given heat input as

$$
\mathrm{HTC}=\frac{Q}{A_{\mathrm{ex}} \Delta T} .
$$

Average values were determined from triplicate repeats, with maximum deviations of + or $-4 \%$.

Air was used to convey sieved rounded sand, ranging in average particle size between $128 \mu \mathrm{m}$ (104-147 $\mu \mathrm{m}), 190 \mu \mathrm{m}$ $(147-295 \mu \mathrm{m})$, and $260 \mu \mathrm{m}$ (208-295 $\mu \mathrm{m})$. $200 \mu \mathrm{m}$ (147$295 \mu \mathrm{m}$ ) limestone was also used. The relevant properties of the powders used in the investigations are listed in Table 2. The minimum fluidization velocity $U_{\mathrm{mf}}$ was experimentally obtained by well-known measurement of the pressure drop across the fixed and fluidized bed. The experimental value was compared with the calculated velocity, using the equation 


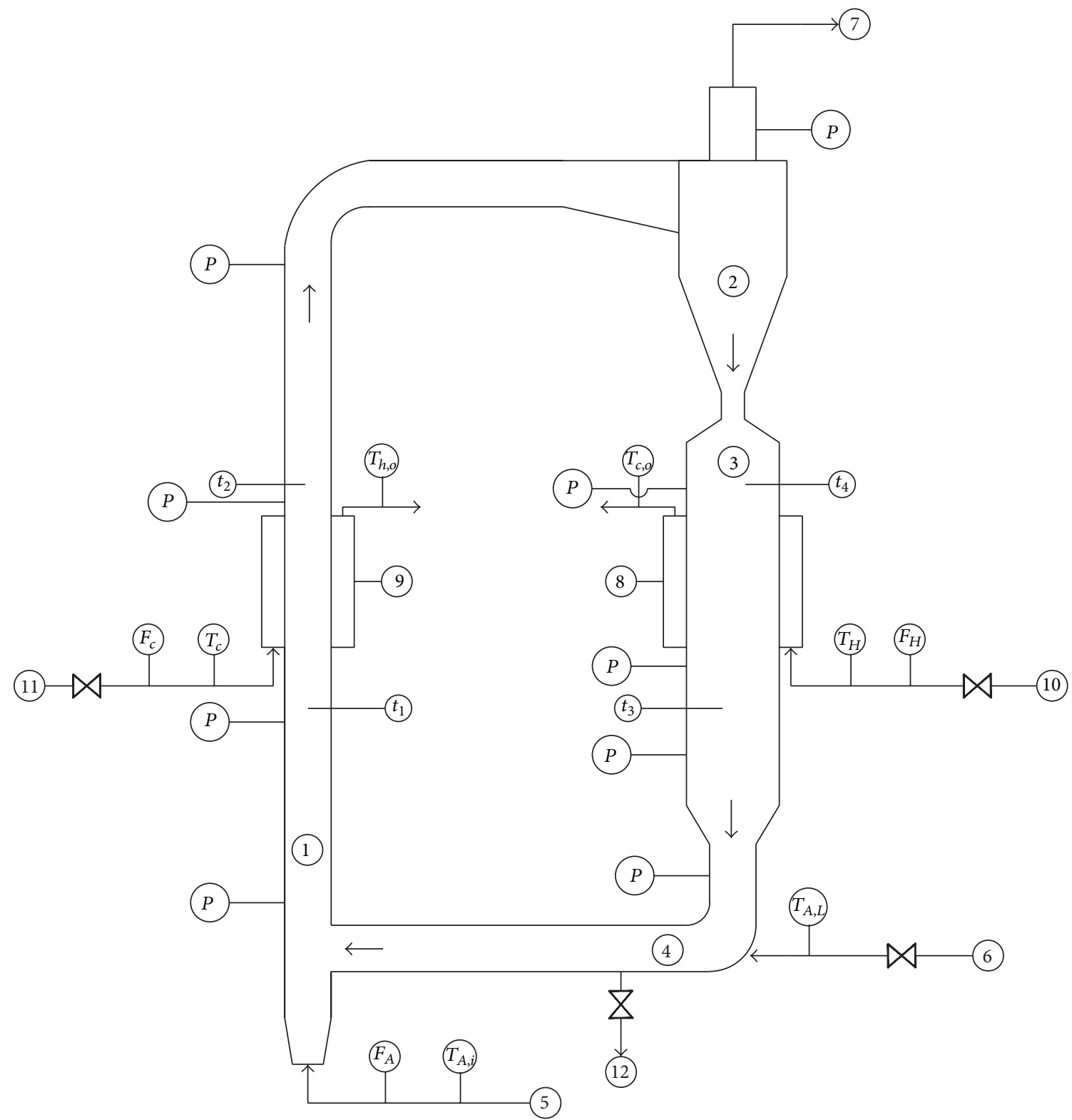

FIGURE 3: Layout of the experimental setup: (1) riser $50 \mathrm{~mm} \mathrm{ID,} \mathrm{(2)} \mathrm{HE} \mathrm{Stairmand} \mathrm{cyclone,} \mathrm{(3)} \mathrm{downcomer} 100 \mathrm{~mm}$ ID, (4) L-valve $50 \mathrm{~mm}$ ID, (5) air from speed-controlled blower, (6) compressed air, (7) vent to baghouse filter, (8) coaxial heating section, (9) coaxial cooling section, (10) supply of thermal fluid, (11) supply of cooling water, and (12) discharge valve. $F_{H}, F_{c}, F_{A}$, and $F_{A, L}$ : respectively, flow meters of thermal fluid, cooling water, riser air, and $L$-valve air; $T$ : temperature probes for respective fluids; $t$ : temperature probes inside riser and downcomer; $P:$ differential pressure probes. $\rightarrow$ solids circulation flow pattern.

TABLe 2: Powder characteristics.

\begin{tabular}{lccccc}
\hline & $d_{\mathrm{sv}}(\mathrm{m})$ & $\rho_{p}\left(\mathrm{~kg} / \mathrm{m}^{3}\right)$ & $\rho_{B}\left(\mathrm{~kg} / \mathrm{m}^{3}\right)$ & $U_{\mathrm{mf}}(\mathrm{m} / \mathrm{s})$ & $\varepsilon_{\mathrm{mf}}$ \\
\hline Sand 128 & 128 & 2620 & 1446 & 0.016 & 0.48 \\
Sand 190 & 190 & 2620 & 1542 & 0.044 & 0.45 \\
Sand 260 & 260 & 2600 & 1520 & 0.080 & 0.42 \\
Limestone & 200 & 2600 & 1560 & 0.048 & 0.45 \\
\hline
\end{tabular}

of $\mathrm{Wu}$ and Baeyens [44]: predicted and experimental values deviated by maximum $\pm 8 \%$.
The absolute particle density $\left(\rho_{p}\right)$ was taken from the suppliers' data. The loosely packed bed density at minimum fluidization $\left(\rho_{B}\right)$ was measured to determine bed voidage $\left(\varepsilon_{\mathrm{mf}}\right)$, given by

$$
\varepsilon_{\mathrm{mf}}=1-\frac{\rho_{B}}{\rho_{p}} .
$$

The solids mass flow rate down the downcomer was determined from weighing the short-sequence discharge of the $L$-valve at point 12 of Figure 3 and compared with the predicted discharge rates by various literature correlations, as 


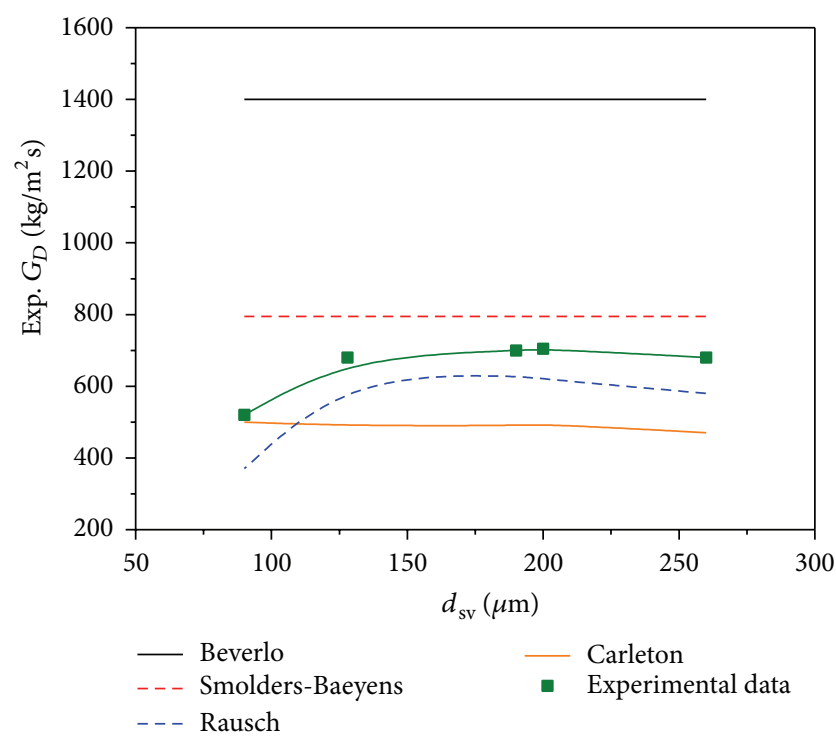

FIgURE 4: Maximum downcomer discharge rate $(D=0.1 \mathrm{~m})$ versus $d_{\mathrm{sv}}$.

further discussed in Section 3.1. An alternative determination of $G_{D C}$ could have been to measure the increasing bed height in the downcomer after stopping the $L$-valve flow.

\section{Results and Discussion}

3.1. Discharge of the Downcomer. Smolders and Baeyens [45] reviewed the literature findings on the maximum discharge rates of gravity-flow from a downcomer (as in the solar heat recovery or biomass pyrolysis, Figure 1) or the hopper apex to discharge powder from the hot or cold storage (Figures 1 and 2). The experimentally determined discharge rate from the downcomer outlet was compared with empirical correlations from Rausch, Beverlo, Carleton, and SmoldersBaeyens, as reviewed by Smolders and Baeyens [46]. Results are illustrated in Figure 4.

Within the rather narrow particle size range investigated, the Rausch and Smolders-Baeyens predictions slightly underestimate and overestimate the experimental findings, respectively. The Carleton and Beverlo predictions are less appropriate. Since the Smolders-Baeyens [46] equation predicts a strong dependency of $G_{\mathrm{DC}}$ with the downcomer diameter $\left(G_{\mathrm{DC}} \sim D^{2.7}\right)$, larger diameter downcomers will be subject to a considerably higher discharge flux than that shown in Figure 4.

3.2. Wall-to-Bed Heat Transfer Coefficients (HTC). The measured HTC appears to be a function of the solids down-flux, as illustrated in Figure 5.

The value of HTC appears to level off at high values of $G_{\mathrm{DC}}$, although experimental results beyond $160 \mathrm{~kg} / \mathrm{m}^{2} \mathrm{~s}$ are needed to confirm this assumption. Literature data are also limited to $\ll 150 \mathrm{~kg} / \mathrm{m}^{2} \mathrm{~s}$, hence not providing evidence of the assumed leveling off. At values up to $\sim 150 \mathrm{~kg} / \mathrm{m}^{2} \mathrm{~s}$, a linear

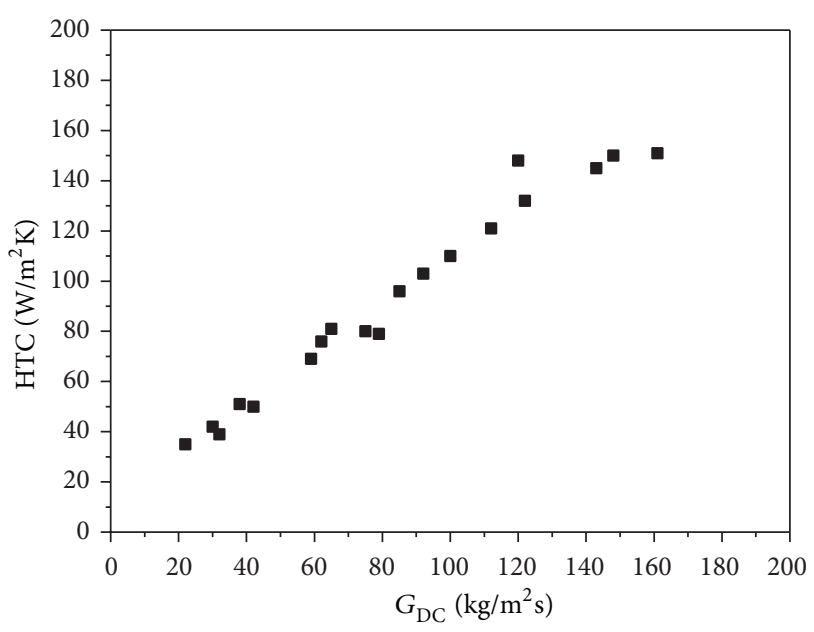

Figure 5: Downcomer wall-to-bed heat transfer coefficient versus solids flux for $128 \mu \mathrm{m}$ sand.

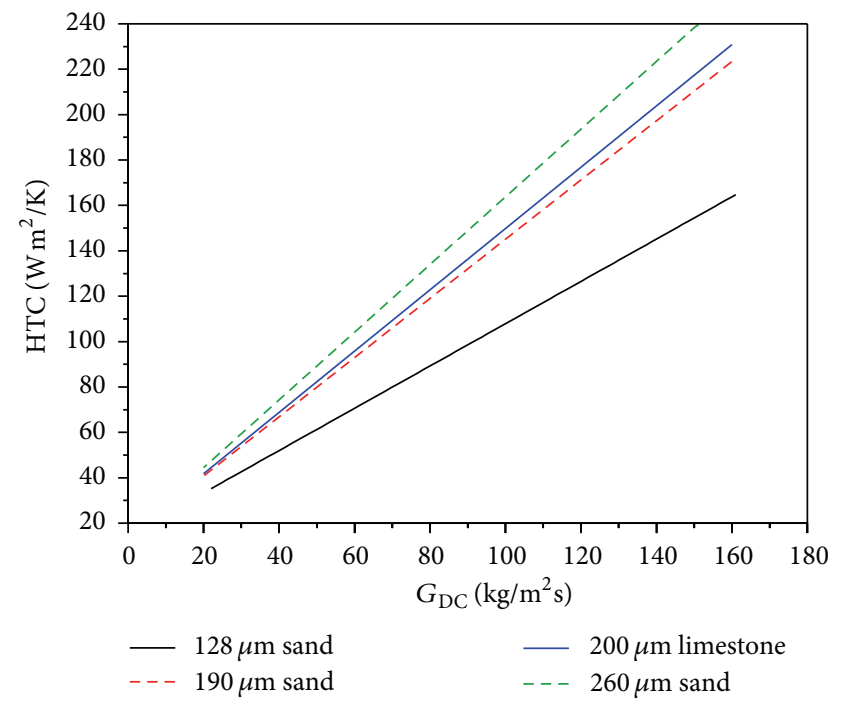

FiguRE 6: Linear fit of HTC for various particles.

trend is seen, for all particles having been tested, as shown in Figure 6.

The heat transfer coefficient increases with increasing particle size, although not proportionally. This increasing heat transfer coefficient with increasing particle size is opposite to what is normally measured in bubbling fluidized beds, where the heat transfer coefficient increases with decreasing particle size.

3.3. The Relationship between Particle Velocity and Heat Transfer. The particle velocity is linked to the solid circulation flux, $G_{\mathrm{DC}}$, by

$$
V_{s}=\frac{G_{\mathrm{DC}}}{\rho_{p}\left(1-\varepsilon_{\mathrm{mf}}\right)}[\mathrm{m} / \mathrm{s}] .
$$

Previous research has already indicated that the particle residence time at the wall, which is controlled by the particle 
velocity, is a major factor affecting the heat transfer coefficient [16]. This is confirmed by our experiments, as shown in Figures 5 and 6, although there appears to be a limit of this effect, since the increase of HTC seems to be leveling off at higher values of $G_{\mathrm{DC}}$. This is probably due to the achievement of a steady state downflow in the downcomer, and by the maximum discharge rate of the downcomer, as demonstrated in Section 3.

Since the particle velocity can be easily determined from $G_{\mathrm{DC}}$, the application of a wall surface renewal model is also possible: similar to bubbling fluidized bed operations [47], the heat transfer to the wall is assumed to be determined by a surface renewal, combined with a heat transfer resistance upon contact, itself being a function of the downflow particle/gas emulsion, with its effective conductivity and film thickness.

The general expression of the surface renewal model [47] determines the heat transfer coefficient in terms of underlying parameters: (i) $c_{p}, \rho_{p}$, and $d_{p}$ as far as particle properties are concerned; (ii) $h_{c}$, the heat transfer resistance upon contact; (iii) $\tau$, the contact time at the surface; and (iv) $\gamma_{p}$, a packing factor of particles at the wall. Consider

$$
\mathrm{HTC}=\frac{\pi \gamma_{p} h_{c}}{1+\left(6 h_{c} / \rho_{p} c_{p} d_{p}\right) \tau} .
$$

In $\mathrm{BFB}$ operations, the contact times at the surface are small (0.1-0.5 s), due to the bubble-induced particle mixing. The heat transfer resistance upon contact, $h_{c}$, was experimentally determined as $h_{c} \sim 3.2 k_{g} / d_{\mathrm{sv}}$ [47]. In downcomers, the contact times are longer (and determined by $L_{\mathrm{DC}}$ and $G_{\mathrm{DC}}$ or $V_{s}$ ) and of the order of seconds. According to Goossens [48], the particle suspension film thickness and its film conductivity and suspension residence time within the film are interrelated. The suspension film thickness is generally an order of magnitude or larger than the particle size used in the experiments, as demonstrated at minimum fluidization conditions [49].

With $6 h_{c} \tau / \rho_{p} c_{p} d_{p} \gg 1$, the equation can be simplified to

$$
\mathrm{HTC}=\frac{\pi \gamma_{p} \rho_{p} c_{p} d_{p}}{6 \tau} .
$$

With $h_{c} \sim 3.2 k_{g} / d_{p}$ [47], the equation can be solved for any particle size and properties, and by calculating the contact time as

$$
\tau=\frac{L}{G_{\mathrm{DC}} / \rho_{p}\left(1-\varepsilon_{\mathrm{mf}}\right)} .
$$

This equation was also developed by Goossens [48], with $\gamma_{p}=1.08$.

Applications of (7) to the current experiments, for example, $128 \mu \mathrm{m}$ with $\tau=L /\left(G_{\mathrm{DC}} / \rho_{p}\left(1-\varepsilon_{\mathrm{mf}}\right)\right)$ and $L_{\mathrm{DC}}=0.2 \mathrm{~m}$, $\varepsilon_{\mathrm{mf}}$ at 0.48 , provide the comparison (Figure 7 ).

The model prediction consistently underestimates the HTC, although by $10 \%$ only at high values of $G_{\mathrm{DC}}$, but

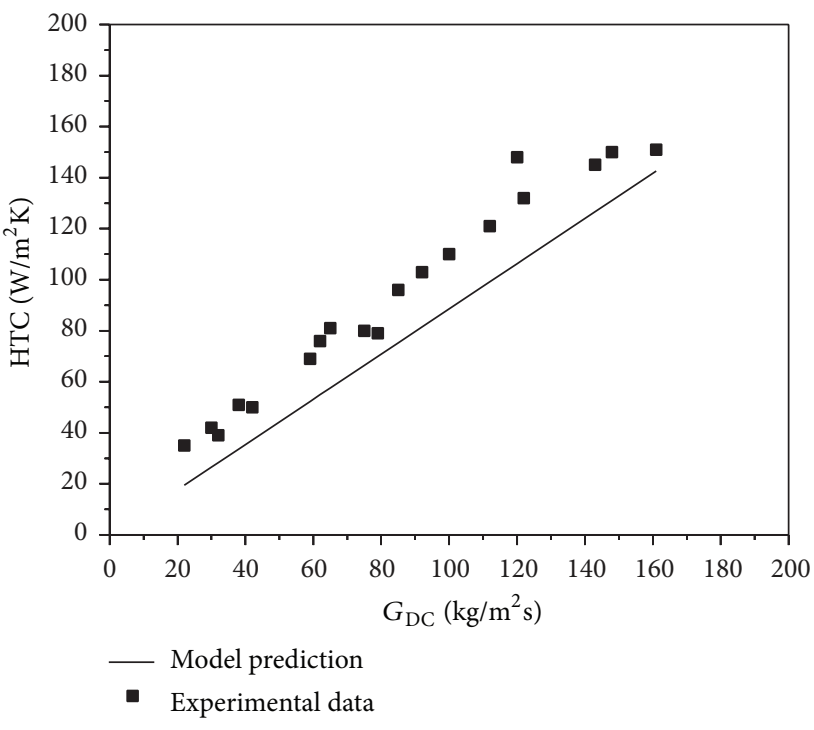

Figure 7: Comparison between model prediction (-) and experimental data (ם).

provides a fair but safe value for design purposes. The reasons for the $10 \%$ discrepancy can be due to the slightly lower renewal time than predicted, due to an occasional bubble rising up the downcomer.

The model equation however demonstrates that the heat transfer coefficient increases with increasing particle size (all parameters of $\rho_{p}$ and $c_{p}$ remaining similar). This increasing heat transfer coefficient with increasing particle size is opposite to what is normally measured in bubbling fluidized beds, where the heat transfer coefficient increases with decreasing particle size.

3.4. Comparison with HTC in the Riser. The values of the heat transfer coefficients in the downcomer are, while lower, not considerably lower than those in the riser [15]. In the riser, the highest heat transfer coefficient is in the lower section where the solids suspension density is high (but without significant dense phase buildup). The heat transfer coefficients in most of the sections of the downcomer and the riser under the similar operating conditions are similar.

\section{Conclusions}

The wall-to-suspension heat transfer coefficient was measured in the CFB downcomer. The HTC increases linearly with the solids flux. The increasing HTC with increasing solid circulation rate is reflected in an increased surface renewal at the wall. The model predictions and experimental data are in very fair agreement. The model expression can hence tentatively predict the influence of the dominant parameters of heat transfer geometry, solids circulation flow, and particle characteristics. 


\section{Nomenclature}

\begin{tabular}{|c|c|}
\hline$A_{\mathrm{ex}}:$ & Surface area of heat exchanger $\left[\mathrm{m}^{2}\right]$ \\
\hline$c_{p}:$ & Specific heat of particles $[\mathrm{J} / \mathrm{kg} \mathrm{K}]$ \\
\hline$D:$ & Diameter of downcomer [m] \\
\hline$d_{p}, d_{\mathrm{sv}}:$ & $\begin{array}{l}\text { Average sieve size and average } \\
\text { surface/volume diameter of particle, } \\
\text { respectively [m] }\end{array}$ \\
\hline$G, G_{\mathrm{DC}}:$ & $\begin{array}{l}\text { Mass flux of solids through the riser or } \\
\text { downcomer, respectively }\left[\mathrm{kg} \mathrm{m}^{-2} \mathrm{~s}^{-1}\right]\end{array}$ \\
\hline HTC: & Heat transfer coefficient $\left[\mathrm{W} \mathrm{m}{ }^{-2} \mathrm{~K}^{-1}\right]$ \\
\hline$h_{c}:$ & $\begin{array}{l}\text { Heat transfer coefficient upon contact of } \\
\text { particles and wall }\left[\mathrm{W} / \mathrm{m}^{2} \mathrm{~K}\right]\end{array}$ \\
\hline$k_{g}:$ & $\begin{array}{l}\text { Thermal conductivity of fluidizing gas } \\
{[\mathrm{W} / \mathrm{m} \mathrm{K}]}\end{array}$ \\
\hline$L:$ & $\begin{array}{l}\text { Height of downcomer heat exchanger } \\
\text { surface }[\mathrm{m}]\end{array}$ \\
\hline$L_{\mathrm{DC}}:$ & Total length of downcomer [m] \\
\hline Q: & Heat input to downcomer wall [W] \\
\hline$U:$ & Superficial gas velocity $\left[\mathrm{m} \mathrm{s}^{-1}\right]$ \\
\hline$U_{\mathrm{mf}}:$ & $\begin{array}{l}\text { Minimum fluidization velocity of powder } \\
{\left[\mathrm{m} \mathrm{s}^{-1}\right]}\end{array}$ \\
\hline$U_{\mathrm{TR}}:$ & $\begin{array}{l}\text { Superficial gas velocity of transition to the } \\
\text { CFB regime }\left[\mathrm{m} \mathrm{s}^{-1}\right]\end{array}$ \\
\hline$V_{g}:$ & $\begin{array}{l}\text { Superficial gas velocity in the downcomer } \\
{\left[\mathrm{m} \mathrm{s}^{-1}\right]}\end{array}$ \\
\hline$V_{s}:$ & $\begin{array}{l}\text { Absolute velocity of solids in the } \\
\text { downcomer }\left[\mathrm{m} \mathrm{s}^{-1}\right]\end{array}$ \\
\hline$V_{r}:$ & $\begin{array}{l}\text { Relative velocity between solids and gas in } \\
\text { the downcomer }\left[\mathrm{m} \mathrm{s}^{-1}\right]\end{array}$ \\
\hline$\Delta P_{\mathrm{DC}}:$ & Pressure drop of downcomer $\left[\mathrm{Pa} \mathrm{m}^{-2}\right]$ \\
\hline$\Delta T:$ & $\begin{array}{l}\text { Temperature difference of the downcomer } \\
\text { wall and the bulk of downflow solids }[\mathrm{K}]\end{array}$ \\
\hline$\gamma_{p}:$ & $\begin{array}{l}\text { Packing arrangement of particle/gas } \\
\text { emulsion film at the downcomer wall }[-]\end{array}$ \\
\hline$\tau:$ & $\begin{array}{l}\text { Average surface renewal time of particles } \\
\text { at the heat exchanger wall }[s]\end{array}$ \\
\hline$\varepsilon, \varepsilon_{\mathrm{mf}}:$ & $\begin{array}{l}\text { Voidage and voidage of powder at } U_{\mathrm{mf}} \text {, } \\
\text { respectively }[-]\end{array}$ \\
\hline$\rho_{g}, \rho_{p}, \rho_{B}:$ & $\begin{array}{l}\text { Density of gas, particle, and bulk bed, } \\
\text { respectively }\left[\mathrm{kg} \mathrm{m}^{-3}\right]\end{array}$ \\
\hline & Viscosity of gas $\left[\mathrm{kg} \mathrm{m}^{-1} \mathrm{~s}^{-1}\right]$ \\
\hline
\end{tabular}

\section{Conflict of Interests}

The authors declare that there is no conflict of interests regarding the publication of this paper.

\section{Acknowledgments}

This study was performed in the framework of the CSP2 (Concentrated Solar Power in Particles) project, funded by the European Commission (FP7, Project no. 282 932). The author Huili Zhang gratefully acknowledges the China Scholarship Council for sponsoring her Ph.D. study at KU Leuven in Belgium (File no. 201206880024).

\section{References}

[1] S. Mahmoudi, J. P. K. Seville, and J. Baeyens, "The residence time distribution and mixing of the gas phase in the riser of a circulating fluidized bed," Powder Technology, vol. 203, no. 2, pp. 322-330, 2010.

[2] C. W. Chan, J. P. K. Seville, X. Fan, and J. Baeyens, "Solid particle motion in a standpipe as observed by Positron Emission Particle Tracking," Powder Technology, vol. 194, no. 1-2, pp. 58-66, 2009.

[3] M. Van de Velden, J. Baeyens, J. P. K. Seville, and X. Fan, “The solids flow in the riser of a Circulating Fluidised Bed (CFB) viewed by Positron Emission Particle Tracking (PEPT)," Powder Technology, vol. 183, no. 2, pp. 290-296, 2008.

[4] M. Van de Velden, J. Baeyens, B. Dougan, and A. McMurdo, "Investigation of operational parameters for an industrial CFB combustor of coal, biomass and sludge," China Particuology, vol. 5, no. 4, pp. 247-254, 2007.

[5] G. Flamant, D. Gauthier, H. Benoit et al., "Dense suspension of solid particles as a new heat transfer fluid for concentrated solar thermal plants: on-sun proof of concept," Chemical Engineering Science, vol. 102, pp. 567-576, 2013.

[6] H. L. Zhang, G. Flamant, D. Gauthier et al., "The use of dense particle suspensions as heat transfer carrier in solar thermal plants," in Proceedings of the 13th World Renewable Energy Congress (WRECXIII '14), Kingston University, London, UK, August 2014.

[7] J. R. Grace, "Heat transfer in circulating fluidized beds," in Circulating Fluidized Bed Technology, P. Basu, Ed., pp. 63-82, Pergamon Press, Oxford, UK, 1986.

[8] J. Grace, "Heat transfer in high velocity fluidized beds," in Proceedings of the 9th International Heat Transfer Conference, G. Hetsroni, Ed., vol. 1, pp. 329-339, Jerusalem, Israel, 1990.

[9] L. Glicksman, "Circulating fluidized bed heat transfer," in Circulating Fluidized Bed Technology, P. Basu and J. F. Large, Eds., pp. 13-29, Pergamon Press, Oxford, UK, 1998.

[10] B. Leckner, "Heat transfer in circulating fluidized bed boilers," in Circulating Fluidized Bed Technology III, P. Basu and M. Hasatani, Eds., pp. 27-38, Pergamon Press, Oxford, UK, 1991.

[11] P. Basu and P. Nag, "Heat transfer to walls of a circulating fluidized-bed furnace," Chemical Engineering Science, vol. 51, no. 1, pp. 1-26, 1996.

[12] K. Everaert, J. Baeyens, and K. Smolders, "Heat transfer from a single tube to the flowing gas-solid suspension in a CFB riser," Heat Transfer Engineering, vol. 27, no. 6, pp. 66-70, 2006.

[13] F. Pitié, C. Y. Zhao, J. Baeyens, J. Degrève, and H. L. Zhang, "Circulating fluidized bed heat recovery/storage and its potential to use coated phase-change-material (PCM) particles," Applied Energy, vol. 109, pp. 505-513, 2013.

[14] A. Brems, G. Cáceres, R. Dewil, J. Baeyens, and F. Pitié, "Heat transfer to the riser-wall of a circulating fluidised bed (CFB)," Energy, vol. 50, no. 1, pp. 493-500, 2013.

[15] H. L. Zhang, J. Baeyens, J. Degrève, A. Brems, and R. Dewil, "The convection heat transfer coefficient in a Circulating Fluidized Bed (CFB)," Advanced Powder Technology, vol. 25, no. 2, pp. 710-715, 2014.

[16] J.-X. Zhu, Z.-Q. Yu, Y. Jin, J. R. Grace, and A. Issangya, "Cocurrent downflow circulating fluidized bed (downer) reactors-a state of the art review," Canadian Journal of Chemical Engineering, vol. 73, no. 5, pp. 662-677, 1995.

[17] J.-X. Zhu and F. Wei, "Recent developments of downer reactors and other types of short contact reactors," in Fluidization VIII, 
J. F. Large and C. Laguerie, Eds., pp. 501-510, Engineering Foundation, New York, NY, USA, 1996.

[18] M. I. Roldán, E. Zarza, and J. L. Casas, "Modelling and testing of a solar-receiver system applied to high-temperature processes," Renewable Energy, vol. 76, pp. 608-618, 2015.

[19] G. Zanganeh, A. Pedretti, A. Haselbacher, and A. Steinfeld, "Design of packed bed thermal energy storage systems for hightemperature industrial process heat," Applied Energy, vol. 137, pp. 812-822, 2015.

[20] H. L. Zhang, J. Baeyens, J. Degrève, G. Cáceres, R. Segal, and F. Pitié, "Latent heat storage with tubular-encapsulated phase change materials (PCMs)," Energy, vol. 76, pp. 66-72, 2014.

[21] M. Van de Velden, J. Baeyens, A. Brems, B. Janssens, and R. Dewil, "Fundamentals, kinetics and endothermicity of the biomass pyrolysis reaction," Renewable Energy, vol. 35, no. 1, pp. 232-242, 2010.

[22] M. Van de Velden, J. Baeyens, and I. Boukis, "Modeling CFB biomass pyrolysis reactors," Biomass and Bioenergy, vol. 32, no. 2, pp. 128-139, 2008.

[23] A. Brems, J. Baeyens, and R. Dewil, "Recycling and recovery of post-consumer plastic solid waste in a European context," Thermal Science, vol. 16, no. 3, pp. 669-685, 2012.

[24] D. Bai, Y. Jin, and Z. Yu, "Momentum exchange between gas and solids in fast fluidized bed," Journal of Chemical Industry and Engineering, vol. 5, pp. 548-553, 1991.

[25] S. Ergun and A. A. Orning, "Fluid flow through randomly packed columns and fluidized beds," Industrial \& Engineering Chemistry, vol. 41, no. 6, pp. 1179-1184, 1949.

[26] T. Baumann and S. Zunft, "Moving bed heat exchanger for solar central receiver power plants: a multi-phase model and parameter variations," in Proceedings of the International SolarPACES Conference, Marrakech, Morocco, 2012.

[27] T. Baumann, S. Zunft, and R. Tamme, "Moving bed heat exchangers for use with heat storage in concentrating solar plants: a multiphase model," Heat Transfer Engineering, vol. 35, no. 3, pp. 224-231, 2014.

[28] M. H. I. Baird, N. V. R. Rao, E. Tackie, and A. Vahed, "Heat transfer to a moving packed bed of nickel pellets," Canadian Journal of Chemical Engineering, vol. 86, no. 2, pp. 142-150, 2008.

[29] H. Zhang, J.-X. Zhu, and M. A. Bergougnou, "Hydrodynamics in downflow fluidized beds (1): solids concentration profiles and pressure gradient distributions," Chemical Engineering Science, vol. 54, no. 22, pp. 5461-5470, 1999.

[30] H. Zhang and J.-X. Zhu, "Hydrodynamics in downflow fluidized beds (2): particle velocity and solids flux profiles," Chemical Engineering Science, vol. 55, no. 19, pp. 4367-4377, 2000.

[31] J. Ball and J.-X. Zhu, "A preliminary study into the local solids fluxes in a downer reactor," Powder Technology, vol. 114, no. 1-3, pp. 96-101, 2001.

[32] H. Chen and H. Li, "Characterization of a high-density downer reactor," Powder Technology, vol. 146, no. 1-2, pp. 84-92, 2004.

[33] P. Lehner and K.-E. Wirth, "Characterization of the flow pattern in a downer reactor," Chemical Engineering Science, vol. 54, no. 22, pp. 5471-5483, 1999.

[34] Y. J. Kim, S. H. Lee, and S. D. Kim, "Coal gasification characteristics in a downer reactor," Fuel, vol. 80, no. 13, pp. 1915-1922, 2001.

[35] Y. Ma and J. Zhu, "Experimental study of heat transfer in a cocurrent downflow fluidized bed (downer)," Chemical Engineering Science, vol. 54, no. 1, pp. 41-50, 1999.
[36] A. I. Tamarin and L. V. Gorbachev, "Measurement of the maximum rate of heat transfer between a bed of moving particles and a surface," Journal of Engineering Physics, vol. 14, no. 1, pp. 37-39, 1968.

[37] Y. J. Kim, J. H. Bang, and S. D. Kim, "Bed-to-wall heat transfer in a downer reactor," The Canadian Journal of Chemical Engineering, vol. 77, no. 2, pp. 207-212, 1999.

[38] P. Lehner and K.-E. Wirth, "Effects of the gas/solids distributor on the local and overall solids distribution in a downer reactor," Canadian Journal of Chemical Engineering, vol. 77, no. 2, pp. 199-206, 1999.

[39] N. S. Obuskovic, Heat Transfer Between Moving Beds of Solids and $a$ Vertical Tube, Oregon State University, 1988.

[40] B. Peters and A. Dziugys, "Heat transfer in fixed and moving packed beds predicted by the extended discrete element method," in Advances in Industrial Heat Transfer, pp. 295-332, CRC Press, 2012.

[41] P. Basu, J. Butler, A. Dutta, and A. Leon, "Heat transfer in standpipe of circulating fluidised bed boiler," Journal of the Energy Institute, vol. 82, pp. 87-94, 2013.

[42] J. Niegsch, D. Koneke, and P.-M. Weinspach, "Heat transfer and flow of bulk solids in a moving bed," Chemical Engineering and Processing, vol. 33, no. 2, pp. 73-89, 1994.

[43] H. F. Meier, D. Noriler, and S. L. Bertoli, "A solution for a heat transfer model in a moving bed through the self-adjoint operator method," Latin American Applied Research, vol. 39, no. 4, pp. 327-336, 2009.

[44] S. Y. Wu and J. Baeyens, "Effect of operating temperature on minimum fluidization velocity," Powder Technology, vol. 67, no. 2, pp. 217-220, 1991.

[45] K. Smolders and J. Baeyens, "Design strategy for a gas/solid circulating fluidized bed reactor," Powder Handling and Processing, vol. 11, no. 3, pp. 257-264, 1999.

[46] K. Smolders and J. Baeyens, "The operation of L-valves to control standpipe flow," Advanced Powder Technology, vol. 6, no. 3, pp. 163-176, 1995.

[47] J. Baeyens, "Modelling approach to the effect of equipment scale on fluidised bed heat transfer data," Journal of Powder \& Bulk Solids Technology, vol. 4, no. 4, pp. 1-9, 1980.

[48] W. R. A. Goossens, Fluid-Bed Heat Transfer, edited by: J. S. M. Botterill, Academic Press, London, UK, 1975.

[49] H. L. Zhang, J. Degrève, J. Baeyens, and R. Dewil, "Wall-tobed heat transfer at minimum gas-solid fluidization," Journal of Powder Technology, vol. 2014, Article ID 163469, 8 pages, 2014. 

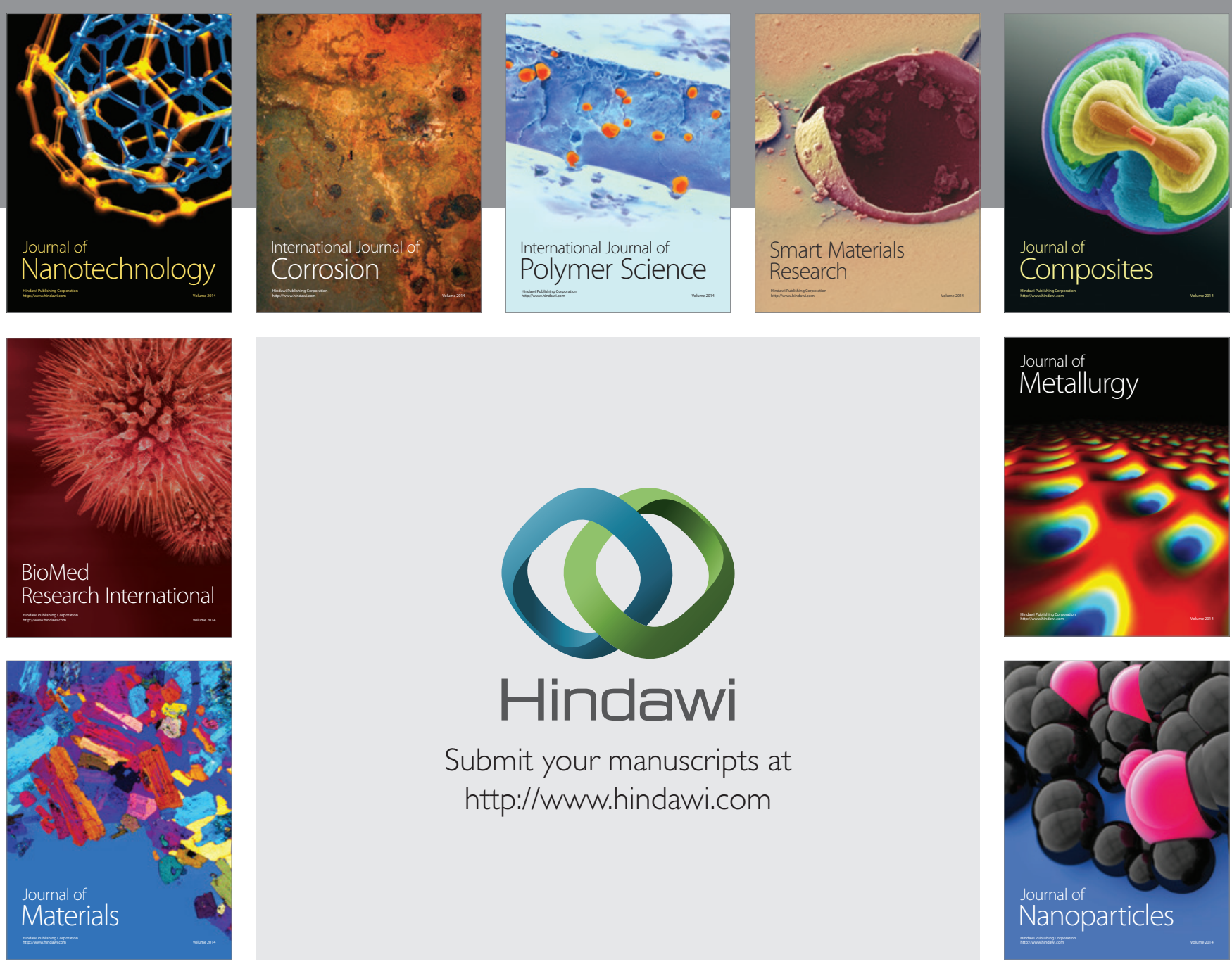

Submit your manuscripts at http://www.hindawi.com
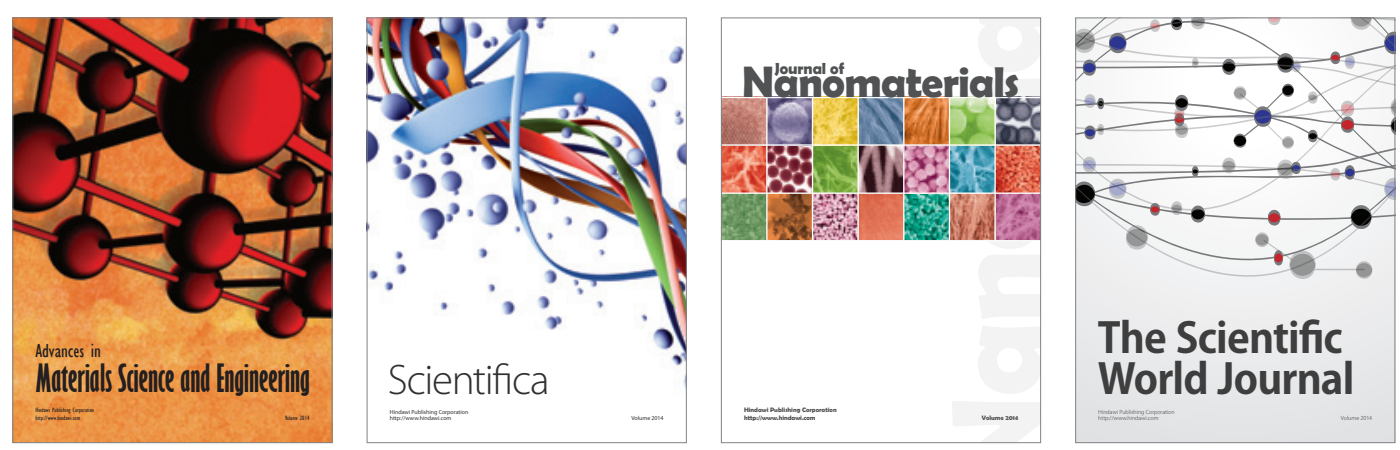

\section{The Scientific World Journal}
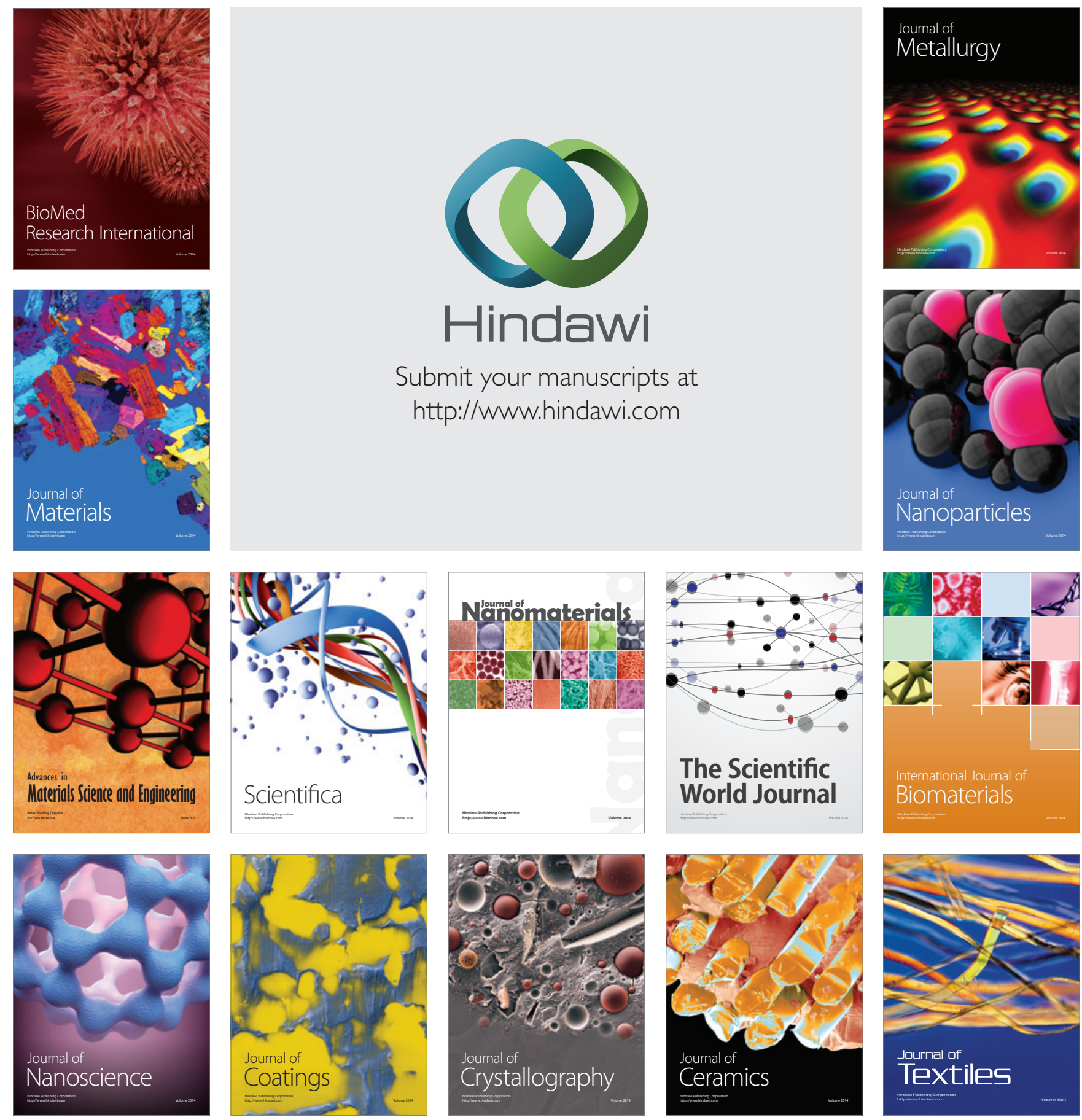